\title{
An Assessment of Teachers' Abilities to Support Blended Learning Implementation in Tanzanian Secondary Schools
}

\author{
Patrick D. Kihoza \\ Nelson Mandela African Institution of Science and Technology, Tanzania \\ Irina Zlotnikova \\ Botswana International University of Science and Technology, Botswana \\ Joseph Kizito Bada \\ Makerere University, Uganda \\ Khamisi Kalegele \\ Nelson Mandela African Institution of Science and Technology, Tanzania
}

\begin{abstract}
The purpose of this study was to describe instances of pedagogical practices of teachers using ICTs and the enhancements of practices using traditional methods, to more fundamental changes in their approach to teaching. Using a mixed method, the research examined the impact of increased education level on the ICT use competence perception and the influence of ICT knowledge level and skills on the adoption of blended learning contents. Four schools were used for this study; two picked out of 50 that are enhanced with ICT infrastructures while the other two were picked from schools without enough ICT infrastructures. Three research questions guided the study. Data collection included teachers, schools inspection officers, curriculum development experts, teacher trainees and policy makers' interviews, questionnaires, classroom observations, and document reviews. Data analysis concentrated on the central questions of the study. The results suggested that teachers' education level couldn't determine their ICT knowledge level. Either, the ICT knowledge level has influences on the decision to use blended learning. Barriers to ICT use in education were revealed as: internal -more of personal attitudes and perceptions about a technology, and external -lack of availability and accessibility to the relevant resources (hardware and software), lack of framework that address integration of ICTs in teaching and learning and unreliable Internet connection. Resulting from the results, this study suggests a goal oriented teacher training framework which should address a complex integration of technology, content, pedagogy, school infrastructures, and the overall objectives of the education systems as trivial of ICT use determining factors.
\end{abstract}

Keywords: Blended learning; Teachers' ICT knowledge; Teachers' ICT use; Teachers' ICT competence; ICT in education.

\section{Introduction}

Current generation is born into a media-saturated world of television, personal computers, mobile devices, radio, films, magazines, newspapers, textbooks, e-books, e-readers, Internet, 
and the World Wide Web that can enhance the quality and effectiveness of education. The Internet with shared global resources has brought a more flexible and dynamic learning environment beyond the traditional book-teacher model which regarded classrooms as the only dominant environment for formal education (Felvégi \& Matthew, 2012). Effective classroom ICT use requires not just content, technology, and pedagogy, but also teachers' knowledge and capabilities to enhance desired social interactions using their relationship. As technology connects more teachers and students, education changes for the better. Realization of the net effect of computer use in classrooms depends on whether computers displace other learning activities or increases the overall time that is spent learning (OECD, 2015 , p. 148). Technology integration fail when there are no instituted strategies for covering the gap between the intended educational objectives viewed as the outcomes of a technologyenhanced education environment for teaching and learning (Buabeng-Andoh, 2012; Voogt, Knezek, \& Roblin, 2015).

The World Bank Group (2003, p. 2) referred ICT to hardware, software, networks, and media for collection, storage, processing, transmission, and presentation of information (voice, data, text, images). However, it is not logical to consider the use of ICT in education as a general term. The use of ICT in education is reported as of four modalities: (1) when ICT relates directly to proper curriculum goals as an integral part; (2) when ICT relates directly to other subsequent classroom activities; (3) when the use of ICTs are separated in place from other learning activities; and (4) when the choice of ICT is proportional to the pedagogical practices and students learning styles (Avidov-Ungar \& lluz, 2014; Ham et al., 2002; Lim, 2006). Some typical examples of the transformative ICT use in education are computer-assisted instruction (also referred to as computer-based learning ) uses computers to aid in the delivery of standalone multimedia packages for learning and teaching (Brown, 2010; Henry, 2001). The use of e-learning also referred to as online learning, Internet-based learning, and Web-based learning which deliver teaching and leaning over the internet (Brown, 2010; Queirós \& Leal, 2010). In other cases, ICT use in education has been referred to as network learning, multimedia-based learning and virtual learning environment referring to the knowledge delivered virtually where a teacher and a learner do not meet physically (Alonso, López, Manrique, \& Viñes, 2005; Daniel, 2009; Knox, 2014; Welsh, Wanberg, Brown, \& Simmering, 2003; Zhang \& Nunamaker, 2003).

In this study, the use of ICT in education is referred to as the availability of both mobile (e.g laptops, mobile phones, tablets, projectors) and non-mobile technologies that could enhance effective teaching and learning. However, technology alone does not guarantee occurrence for deep learning. The use of ICT resources that supports instruction (e.g. CD-ROM based video, projectors, moving images, video conferencing, bulletin boards for discussion etc.) has more impacts on students learning than technology applications that provide direct instruction (e.g. Internet services, multimedia learning content) (Tamim, Bernard, Borokhovski, Abrami, \& Schmid, 2011). The availability of committed teachers, supportive learning environment and the technology use enhanced infrastructures guarantees learners moving from 3Rs (reading, writing and arithmetic) competences to the deep learning and broader skills of 4Cs (creativity, communication, collaboration and critical thinking) of which using ICTs have the ability to develop (Cox et al., 2003, p. 31; Keane, Keane, \& Blicblau, 2014; Markauskaite, 2007).

The rapid advances in information and communication technologies (ICTS) have positive impacts on the effectiveness of pedagogical methods and knowledge delivery. The growing number of alternatives for ICT usage, with their multiple media text, visual, voice and their 
capacity that could extend interaction over time and space, are transforming teaching and learning. The use of blended learning (a model of e-learning) enhances mixing of ICT use and traditional approaches where digital contents can be used offline or online accessed, downloaded or distributed as electronic media (e-books, media graphics, images, podcasts, videos files, simulations, animations, online tutorials and assignments, subject related webpages and Web 2.0 tools) (Intel Corporation, 2012; Jia et al., 2013; Pankin, Roberts, \& Savio, 2012; Saliba, Rankine, \& Cortez, 2013). Blended learning is a structured opportunity to learn, using more than one learning methods, carried out inside or outside the classroom and supported by technology and tradition methods (Pankin et al., 2012). The aspects in the use of blended learning are based on supported instructional methods, delivery methods, scheduling and different levels of guidance (Thorne, 2003, p. 29). Its use increases flexibility, quality, and effectiveness of learning process subsequent to an improved productivity of both teachers and learners (Holt, Segrave, \& Cybulski, 2012, p. 30; IICD, 2014).

The complexities of ICT infrastructures availability in many schools and characteristics of teachers' personal knowledge, abilities and competences to use ICTs do not lend them to easy or sophisticated solutions. The UNESCO ICT framework for teachers described ICT use competences among professional teachers' as: (1) Beginner (with abilities to integrate technology as pedagogy and use ICT basic tools in teaching); (2) Average user (with abilities to demonstrate a general competency in a number of computer applications); and (3) Advanced user (with abilities to competently use a broad diversities of ICT devices and tools) (UNESCO, 2011, p. 17). Teachers becomes active blended learning users when they can prepare activities for teaching (browsing to prepare lessons, preparing tasks for students, preparing presentations, collecting online resources to be used during lessons) (European Union, 2013, p. 80).

The opportunities afforded by the use of ICTs in education are many; the ineffectiveness of teachers' ICTs practices and the unsupportive philosophies of traditional teaching methods have made them unrealistic (Mckensey \&Company, 2011). Recently, it was reported that teachers' digital literacies, educational ICT training, and ability to access the Internet are among important determinants of their belief on importance of the instructional benefits of digital technologies (Badia, Meneses, Sigalés, \& Fàbregues, 2014). Critical challenges to technology adoption in education could either be internal (e.g. personal attitudes and perceptions about a technology) or external (e.g. availability and accessibility to the relevant hardware and software, institutional support, staff development program and training) (Albugami \& Ahmed, 2015; Andersson \& Grönlund, 2009; Mumtaz, 2000). A study by Straub (2009)reported that for technology use in education to remain sustainable, personal factors (e.g skills, knowledge, competencies, readiness etc.), characteristics of the innovation (e.g. personal experimentation ), and influences of the individual's context should never be ignored as part of the planning process. However, teachers have a central role in developing new learning models in schools; moving them from gaining basic ICT skills, to conducting ICTfocused lessons and eventually appropriate ICT integration should start from institutions that nurture them (Schibeci et al., 2008).

\section{ICT in Education Initiatives in Tanzania Secondary Education}

The ICT Policy for Basic Education (United Republic of Tanzania, 2007, p. 15) recognized the use of ICT devices in education (such as personal computers, digital cameras, scanners, 
projectors, telecommunications equipment, Internet resources, radio and TV) as potential for improving quality and effectiveness of teaching and learning. However, few teachers use ICTs in classrooms irrespective to the investments made in the ICT supportive infrastructures in teachers training colleges and few secondary schools (Andersson, Nfuka, Sumra, Uimonen, \& Pain, 2014, p. 28).

The ICT initiatives in Tanzania primarily ensured that schools had access to sufficient hardware, through specified computer-to-school laboratory target ratios, and be networked. The eSchools forum in 2005 proposed a phased approach with Phase I (2006 to 2008) projected to have more than 2000 schools with ICT tools by 2015 (Hooker, Mwiyeria, \& Verma, 2011; Nyirenda, 2013). The National Programme for ICT for Secondary Schools' Teachers initiative 2005 to 2008 targeted to eradicate ICT illiteracy among teachers and enhance its use in teaching (Hooker et al., 2011). To its completion, the project supported 50 secondary schools and all 34 government teachers' colleges with blended learning infrastructures and digital learning contents(Andersson et al., 2014, p. 6). The SME (Science, Mathematics and English)-ICT project offered digital materials for teaching Science, Mathematics and English subjects on DVDs and CDs where selected schools were supplied with LCD projectors and laptops and also teachers trained on the use of ICTs (GESCl, 2011a). The SME-ICT project had twofold objectives: first, to train teachers on how to use ICTs as pedagogical tools and, second, to create access and availabilities of blended curriculum contents for teaching science, basic mathematics, and English. However, in the teacher training colleges there is much good practice in teaching ICT as a subject, but less pedagogical ICTs practices and effective teaching strategies using ICTs. Both external and internal limitation may exist, the only challenges reported to have limited tutors (Teachers training college trainers) ICT use are insufficient availability of ICT resources and lack of sustainable internet connection and power supply. The ICT knowledge and skills teacher trainees receive from tutors have impact on their transitive future use of pedagogical ICTs when they enter job markets as qualified teachers. However, recently Ndibalema (2014) reported low usage of ICTs among secondary school teachers in Tanzania that were attributed to the ease of use, teachers' background in formal training and teachers' attitudes towards technology.

In most cases, the use of ICTs among teachers in secondary schools in Tanzania has been perceived as general practices. In teacher training practices, ICTs have often being assumed to mean only internet and computers, while there are many teacher training needs that ICTs could offer as a solutions to deliver e-learning models to pre-service and in-service teachers (Baker, Bliss, Chung, \& Reynolds, 2013, p. 18). However, availability of hardware and software has been given more priorities when compared to the accessibility of localized curriculum relevant e-contents. The notion of previous investments on educational ICTs being relied much on ICTs as infrastructures and less on pedagogical ICTs application still exists in most Sub-Saharan Africa (Dumont \& Istance, 2010; Farrell, Isaacs, \& Trucano, 2007). Few years ago, private schools were more advantaged when compared to public schools which suffered from ICT resources unavailability and teachers' ICT use incompetence's (Swarts \& Wachira, 2010). Although public schools and private schools receive teachers graduated from the same colleges and universities, studies do not tell why internal barriers should exist when both are given equal chances to practice technological, pedagogical and contents Knowledge's comprehensively. By gathering evidence about the education environment and the desired interactions for the classroom and analyzing and evaluating them, one may determine the level of technology and training strengths as well as the areas in which improvements should be made (Patnoudes, 2014). 
A project evaluation on ICT use in teaching and learning in teachers training colleges found only $44 \%$ as active ICT users, regardless of the ICT infrastructures and training which were being offered (Andersson et al., 2014, p. 6). However, ICT use in secondary education initiatives in Tanzania focused on ICTs as a general term without specifying the model of ICT integration, there should be a model and an education objective to achieve. In a study by Olson et al (2011, p. iv), it was reported that blended approach can provide the highest learning outcomes in African countries where secondary teachers have little prior experience with computers or similar technologies because of its ability to support mixing face-to-face classroom methods with technology-mediated activities.

There are few literature pieces on how teachers can be shaped to use and deliver education using ICTs as pedagogical tools compared to how teachers can and should be trained in the use of ICTs. However, they are both important. Without a defined ICT use and teacher training models with ICT pedagogical application relevance, teachers will lack important skills, competencies and the understanding of the ICT as a solution and hence becomes ineffective (Baker et al., 2013, p. 18). Thus, this study focused on assessing teachers' ICT knowledge level, skills, and their transitive impacts on the ICT pedagogical practices.

\section{Research Objectives}

The lack of a well-defined pedagogical ICT application focus to most of professional teachers and teacher trainees in the teacher training colleges reflects the lack of a common understanding of the specific ways the technology can enhance teaching and learning. This is further affected by the constantly changing face of the technology itself. When the existing syllabi focus more on teaching ICT as a subject rather than using it as a learning tool, it is a high time to redefine the model of ICT use initiatives where the digital generation should be guided to use technology as their own and move with it into the future. However, teachers must develop knowledge and skills on current technologies order to gain the experience necessary to understand the potentials of digital technologies in education, teachers training colleges should be the major vehicle for developing their pedagogical ICT competencies pertinent to the endowed knowledge. Teachers should be responsible for developing the attitudes necessary for pedagogical ICT capabilities and practices.

Given that some of the precise and detailed knowledge of teaching using ICT that teachers must retain after departing from training colleges may be short-lived, this study assessed-what knowledge, skills, understanding and experiences teachers have that signify continued ICT use in teaching. Currently, it is unknown how the professional teachers in the field and teacher trainees graduating from teachers' training colleges are using their ICT knowledge and skills in teaching ICT in schools and practically use ICTs as pedagogical tools. This study discloses ICT knowledge, skills, and competences of teachers and the existing model of ICT in education integration. The study also reveals the most relevant model of pedagogical ICTs practices for secondary schools in Tanzania. Three key research questions were of primary use:

-What are the teachers' perceptions in relation to the personal ICT use competences?

- Could teachers' education level determine their ICT use knowledge level and skills?

- How teachers' ICT knowledge level and skills have contributed to the classroom practices of blended learning contents? 
To answer those questions, the study focused on teachers and teacher trainees whose specialties were Basic Mathematics and Science. Two of the previous ICT in education initiatives in Tanzania focused on the use of ICT in teaching Mathematics, Science and English (Andersson et al., 2014; GESCl, 2011b). Science subjects are Physics, Chemistry, and Biology. Parameters used by this study to answering the research questions are:

- teachers' ICT knowledge level and the implementation of blended learning,

- the digital educational resources and how teachers use them,

- teachers' preparedness for using and digital educational resources in classrooms, and

- the factors limiting technology use in schools.

The following hypothesis supported parameter (2) for teacher trainees, Null Hypothesis (Ho): "The increase in teacher trainees' education level does not lead to increased ICT knowledge level (competence)". Alternative Hypothesis (H1): "The increase in teacher trainees' education level leads to increased ICT knowledge level (competence) ". In addition, parameter (2) for teachers was assed using Null Hypothesis (Ho): "Teachers education level does not lead to increased ICT knowledge level (competence)". Alternative Hypothesis (H1): "Teachers education level leads to increased ICT knowledge level (competence).

\section{Design of the Study}

\section{Research Methodology}

This was a survey research design employed to collect data using both questionnaires and interviews. This study involved 235 participants made by groups of actors in the areas of secondary education practices, quality control, management and policy formulation. The five data sources were: (1) teachers from four secondary schools, (2) secondary schools in Central Zone Inspectorate Division, (3) Tanzania institute of Education (Government agency for curriculum development), (4) Teacher trainees from one teacher training college and one university and (5) Ministry of Education and Vocational Training (MoEVT) officials. Teachers and teacher trainees specialized in basic mathematics and science subjects individually were given the option of not participating. No incentives were given for participation. Assumption made was, despite that teacher trainees are not yet assigned to schools, at least once they have participated in a one or more than one month field practice of teaching where they should have used or exposed to pedagogical ICT tools application to demonstrate their ICT use competences and knowledge levels.

\section{Population and Sample}

A list of 50 secondary schools that had previously participated in ICT projects was collected from the Ministry of Education and Vocational Training (see Section "Blended Curriculum Content Initiatives in Secondary Education" of this paper). The list guided us to identify schools which have received supportive ICT use infrastructures and training offered to some teachers. In total, the study assessed four secondary schools, among which two schools were randomly selected from the 50 schools and other two schools were randomly selected out of more than 2000 public schools that had never participated in any ICT projects. 
Teachers participated were randomly selected from two rural schools and two urban schools both of Morogoro region in which three were day schools and one was boarding school. We used strata (categorical) of individuals to ensure that we focused on all diverse characteristics in the sampling process representation according to Kothari (Kothari, 2004, p. 36). The mutual influence was that all four schools used the same curriculum, though had different supportive infrastructures, management and teachers creativity when using available teaching resources differs.

The sample included three employees from the Ministry of Education and Vocational Training representing policymakers, 24 teachers from four secondary schools, 194 teacher trainees were made by 158 from Morogoro TTC and 36 from Mzumbe University, four zone inspection officers specialized in Basic Mathematics and Science subjects and 10 curriculum developers from the Tanzania Institute of Education. We dealt with participants specialized in science and mathematics as a way to find out how science and mathematics learners in Tanzania can benefit from the rich pedagogical digital educational resources that are available offline and online.

Table 1. Distributions of Respondents

\begin{tabular}{lll}
\hline & Frequency & Percentage \% \\
\hline Teachers & 24 & 10.2 \\
Inspectorate Division & 4 & 1.7 \\
Curriculum Developer & 10 & 4.3 \\
Teacher Trainees & 194 & 82.6 \\
MoEVT & 3 & 1.3 \\
Total & 235 & 100.0 \\
\hline
\end{tabular}

Three Ministry of Education officials participated in the interviews; one from the teacher training department, one from the commissioners' departments, and one from the secondary school education department. The secondary schools and teacher training institutions involved in the study were all public located in Morogoro region. Condition for teachers' participation was that, he/she should be teaching basic Mathematics or Science. Out of 24 participated teachers' school wise distributions were nine from Kilakala (37.5\%), six from Mongola (25.0\%), five from Kipera (20.8\%) and four from Lupanga (16.7\%). Generally, targeted population for data collection was in-service teachers, teacher trainees, curriculum developers, policy makers, and school inspectors.

\section{Data Gathering Tools}

Data were collected using structured questionnaires, formal interviews, document reviews, and observations. Three separate questionnaires were used in this study; namely technology level of use developed by Al-Zaidiyeen, Mei, and Fook (2010), professional teachers ICT knowledge levels identified by UNESCO (2011, P.7), in-service teachers and teacher trainees perceived abilities toward classroom technology integration developed by Spaulding (2007) and barriers to implementation of ICT use in secondary education adopted from Jones (2004).

The firs questionnaire included seven items used to measure teachers ICT knowledge level and ICT tools practices. The ICT tools practices were grouped as either online ICT tools or offline ICT 
tools. A four point Likert scale format was used to assessing teachers ICT knowledge level and ICT tools use frequencies ( $1=$ never use, $2=$ rarely use, $3=$ sometimes use, $4=0$ often use). The ICT use competences were assessed based on knowledge level perception, where teachers and teacher trainees had three choices- beginner, average, and advanced users (UNESCO, 2011, P.7).

The second questionnaire contained 13 items measuring teachers and teacher trainees' perceived preparedness on the use of specified ICT tools or practices as an indication of the abilities toward classroom technology integration (Spaulding, 2007). However, some teachers and teacher trainees may have gained ICT use skills out of formal education; in this study, assumption was made that they should base their response on the formal education they have received. The questionnaire was designed as three-point Likert scale; where $1=$ prepared, $2=$ poorly prepared, $3=$ not prepared.

The third questionnaire contained seven lists of items measuring perceived barriers faced by teachers for classroom technology integration (Jones, 2004). The questionnaire was designed as five-point Likert scale; where $1=$ =strongly disagree, $2=$ disagree, $3=$ uncertain, $4=a g r e e$, and $5=$ strongly agree.

The MoEVT officers' interviews, which took place a week after followed completion of the survey. The study arranged and scheduled the interview sessions to take place within a free time to avoid interruptions that could have happened during busy time. Interview questions were not issued to responds before the session to avoid preparing of answers that would have misled the study.

Document review was only conducted in secondary schools that involved examining ICT lending book to identify the frequencies of ICT tools lending among teachers and the subjects areas they teach. The use of observations involved a school visit and classroom walk-in in which about 2 randomly selected classes were observed for roughly 15 minutes each to obtain a perspective on routine teaching practices that involved pedagogical ICTs. The classes visited were selected based on the records revealed in the ICT lending book.

\section{Data Analysis Procedures}

Teachers and teacher trainees responded to a survey questionnaire, which was filled out under the research team's loose supervision in each school and teacher training institution. Time allocated for the questionnaire completion was one hour, which they were collected after. Respondents were allowed to ask questions for anything that needed elaboration; however, they were not allowed to discuss for obtaining collective responses among themselves. The collected data were processed by using Statistical Package for Social Science (SPSS) program, version 17. It was used to analyze data as follows:

- The Pearson's correlation coefficients were used to identify the relationships between the ICT knowledge level of ICT use and the selected factors.

- The descriptive statistics used for summarizing data included frequency percentages, means, and standard deviations. 


\section{Issues of Validity and Reliability}

To increase validity, five data sources were used to combine and cross reference the findings from these sources. Key sources of data were:

- Secondary school staff teachers regardless of their working experiences.

- Teacher trainees (those pursuing diploma in education as TTC students and Bachelors in education university students specializing in Mathematics and Sciences)

- Central zone secondary schools' inspectors who by default must have practiced teaching before being assigned to be inspection officers

- Public servants working as curriculum development experts

- Ministry of Education and Vocational Training employees from the Secondary Education Department, Education Commissioner's Office, and Teacher Training Department both considered as policy makers and planning officers.

For example, in practice survey questionnaires provided background information about the participants, and an indication of their ICT knowledge levels with various digital educational resources' practices. Observations revealed teachers' actual technology use in the classroom and the availability of infrastructural support from the schools we visited. Both formal and informal interviews were conducted to schools' inspectors and few teachers to understand how teachers' beliefs, altitudes and social behavior influenced technology classroom practices. This enhanced validity of the data that were collected and used for this study.

Cronbach's alpha test of reliability and internal consistency was conducted on each of the items assessed and the results revealed perceived digital educational resources usage $(\alpha=$ $0.778, n=7)$, context for use that supports blended learning $(\alpha=0.899, n=13)$ and the perceived barriers to technology readiness $(\alpha=0.722, n=7)$. The Alpha coefficients $(\alpha>0.70$ are considered acceptable and ( $\alpha>0.8$ is Good (Bland \& Altman, 1997; Santos, 1999).

\section{Findings}

\section{Relationships between ICT Knowledge Level Perception and Education Level/Year of Study}

The association between ICT knowledge level and the education level for teacher trainees was assessed using a cross tabulation followed by a Pearson chi-square test. Null Hypothesis (Ho): "The increase in teacher trainees' education level does not lead to increased ICT knowledge level (competence)". Alternative Hypothesis (H1): "The increase in teacher trainees' education level leads to increased ICT knowledge level (competence) ".

The results of a survey of 194 teacher trainees are presented in Table 2 below while Pearson Chi-square test is in Table 3 below. 
Table 2. Teacher Trainees Study Level and ICT Knowledge Level Cross Tabulation ( $N=194)$

\begin{tabular}{|c|c|c|c|c|}
\hline \multirow[b]{2}{*}{ Year of Study } & \multicolumn{3}{|c|}{ ICT Knowledge Level } & \multirow[b]{2}{*}{$\begin{array}{l}\text { Total } \\
\mathbf{f}(\%)\end{array}$} \\
\hline & $\begin{array}{c}\text { Beginner } \\
f(\%)\end{array}$ & $\begin{array}{c}\text { Average } \\
\text { f (\%) }\end{array}$ & $\begin{array}{l}\text { Advanced } \\
\text { f (\%) }\end{array}$ & \\
\hline $1^{\text {st }}$ Year & $(63) 32.5$ & (18) 9.3 & (10) 5.2 & $(91) 46.9$ \\
\hline $2^{\text {nd }}$ Year & (60) 30.9 & (24) 12.4 & (9) 4.6 & (93)47.9 \\
\hline $3^{\text {rd }}$ year & (2) 1.0 & (7) 3.6 & (1) 0.5 & $(10) 5.2$ \\
\hline$\%$ of Total & 64.4 & (49) 25.3 & 10.3 & (194)100.0 \\
\hline
\end{tabular}

The Chi-square test was carried out to test if there is a relationship between the education level (increased in the year of study) and the teacher trainees ICT knowledge level.

Table 3. Chi-Square Results for Relationship between Education and ICT Knowledge Levels of Teacher Trainees

\begin{tabular}{|l|r|r|r|}
\hline & \multicolumn{1}{|c|}{ Value } & \multicolumn{1}{|c|}{ df } & \multicolumn{1}{|c|}{ Asymp. Sig. (2-sided) } \\
\hline Pearson Chi-Square & $12.485^{\mathrm{a}}$ & 4 & .014 \\
Likelihood Ratio & 11.105 & 4 & .025 \\
Linear-by-Linear Association & 2.169 & 1 & .141 \\
N of Valid Cases & 194 & & \\
\hline
\end{tabular}

a. 2 cells (22.2\%) have expected count less than 5 . The minimum expected count is 1.03 .

A Pearson Chi-square test was conducted to examine whether there was a relationship between teacher trainees' increased education level (year of study) and the ICT knowledge level (Competence). The results revealed that there was no significant relationship between the two variables (Chi square value $=12.49, \mathrm{~N}=194$, $\mathrm{df}=4, \mathrm{p}>0.001$ ). The null hypothesis is accepted, since $p>0.001$. A significantly proportion of teacher trainees $(64.4 \%)$ reported of being beginner user, with majority $(32.5 \%)$ from $1^{\text {st }}$ year and $(30 \% .9)$ from $2^{\text {nd }}$ year of study.

This study also assessed if there was any relationship between ICT knowledge level and the education level of teachers. A cross tabulation was performed followed by a Pearson Chisquare test. Null Hypothesis (Ho): "Teachers education level does not lead to increased ICT knowledge level (competence)". Alternative Hypothesis (H1): "Teachers education level leads to increased ICT knowledge level (competence) ". The results of a survey of 24 teachers are presented in Table 4, while Pearson Chi-square test is in Table 5.

Table 4. Teachers' Education Level and ICT Knowledge Level Cross-Tabulation ( $\mathrm{N}=24)$

\begin{tabular}{lllll}
\hline \multirow{2}{*}{ Education Level } & \multicolumn{3}{c}{ ICT Knowledge Level } \\
& $\begin{array}{l}\text { Beginner } \\
\mathbf{f ( \% )}\end{array}$ & $\begin{array}{l}\text { Average } \\
\mathbf{f ~ ( \% )}\end{array}$ & $\begin{array}{l}\text { Advanced f } \\
\text { (\%) }\end{array}$ & $\begin{array}{l}\text { Total } \\
\mathbf{f ~ ( \% ) ~}\end{array}$ \\
\hline Masters/Postgraduate & $(2) 8.3$ & $(1) 4.2$ & $(0) 0.0$ & $(3) 12.5$ \\
Bachelor/Adv.Diploma & $(7) 29.2$ & (5) 20.8 & (3) 12.5 & (12) 62.5 \\
Diploma Certificate & (4) 16.7 & (2) 8.3 & (0) 0.0 & (6) 25.0 \\
\% of Total & (13) 54.2 & (8) 33.3 & (3) 12.5 & (24) 100.0 \\
\hline
\end{tabular}


The Chi-square test was carried out to test if there is a relationship between the education level (increased in the year of study) and the teacher trainees ICT knowledge level. However, a Chi square test is conducted on a sample with a smaller size, to avoid making conclusion on inaccurate inference it was supported by the cross tabulation results.

Table 5. Chi-Square Results for Relationship between Education and ICT Knowledge Levels of Teachers

\begin{tabular}{|l|r|r|r|}
\hline & \multicolumn{1}{|c|}{ Value } & \multicolumn{1}{|c|}{ df } & Asymp. Sig. (2-sided) \\
\hline Pearson Chi-Square & $2.215^{\mathrm{a}}$ & 4 & .696 \\
Likelihood Ratio & 3.225 & 4 & .521 \\
Linear-by-Linear Association & .127 & 1 & .722 \\
N of Valid Cases & 24 & & \\
\hline
\end{tabular}

a. 7 cells (77.8\%) have expected count less than 5 . The minimum expected count is .38 .

A Pearson Chi-square test was conducted to examine whether there was a relationship between teachers education level and the ICT knowledge level (Competence). The results revealed that there was no significant relationship between the two variables (Chi square value $=2.22, N=24, d f=4, p=0.696$ ). The null hypothesis is accepted, since $p>0.05$ (in fact $p=$ 0.696). A significantly larger proportion of teachers (54.2\%) reported of being beginner user comprising majority (29.2 \%) with Bachelor's degree /Adv.Diploma and (16.7\%) with Diploma Certificate.

\section{Teachers' ICT Knowledge Level and Perceived Rate of Blended Leaning Contents Practices}

This part focused on online- and offline-based digital educational resources that positively support blended learning curriculum implementation. Teachers and teacher trainees were assessed differently in each aspects and then results compared.

\section{The Rate of Online-based Digital Educational Resources Practices}

After teachers had completed rating their personal ICT knowledge level (competence) in which 1 represented beginner, 2 represented average and 3 represented advanced; then they were asked to rate their ICT use behavior (level of frequencies) with a range of ICT resources that depend on connectivity being provided. A rating of 1 represented never use, whereas the rating of 4 represented often use. Figure 1 provides summary of the teachers' ICT knowledge level against the ICT tools use frequency. 


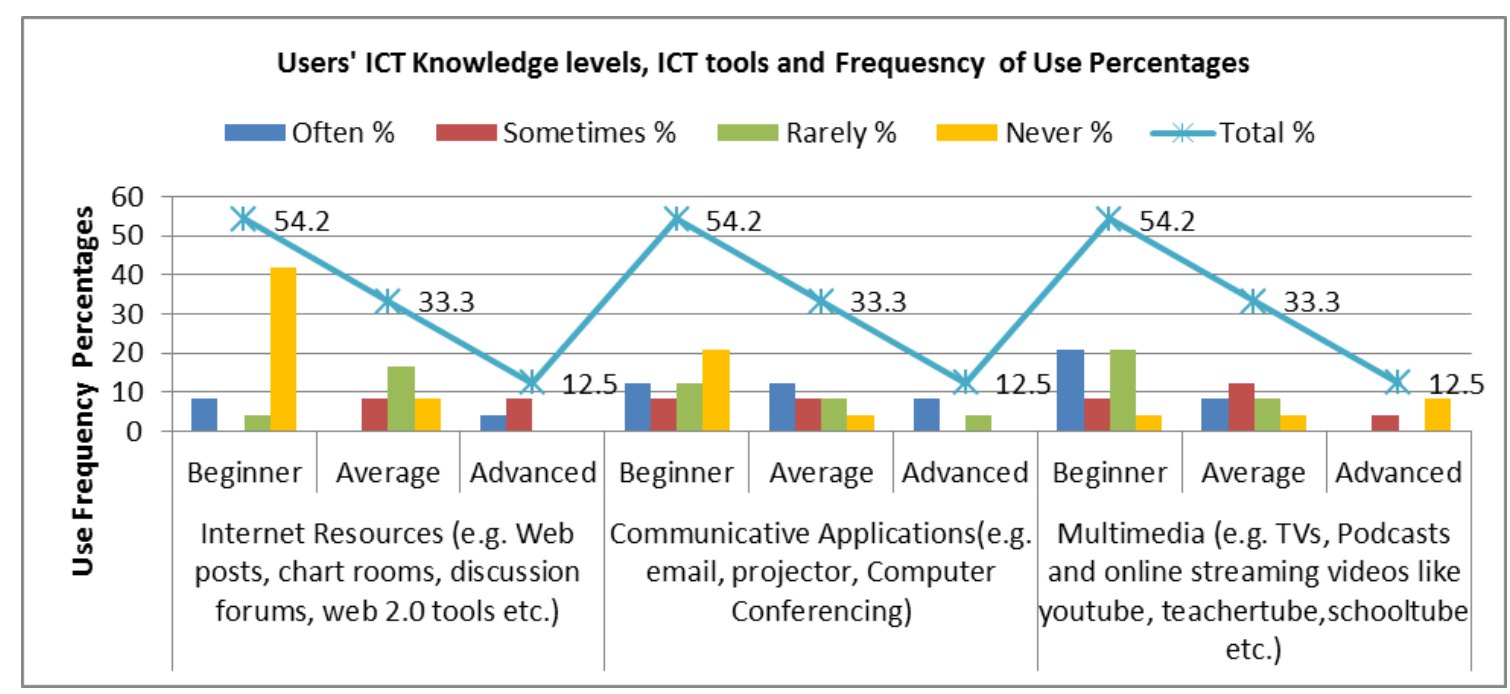

Figure 1. Teachers' ICT Knowledge Level and the Rate of Online Based ICT Tools Practices ( $N=$ 24)

Results in Figure 1 above revealed that, majority of beginner teachers reported to have never used Internet resources were (41\%), never used communicative applications (20\%), while $20 \%$ reported to have often and rarely used multimedia respectively.

In addition, after teacher trainees had completed rating their personal ICT knowledge level (competence) in which 1 represented beginner, 2 represented average and 3 represented advanced; then they were asked to rate their ICT use behavior (level of frequencies) with a range of ICT resources that depend on connectivity being provided. A rating of 1 represented never use, whereas the rating of 4 represented often use. Figure 2 provides summary of the teacher trainees' ICT knowledge level against the ICT tools use frequency.

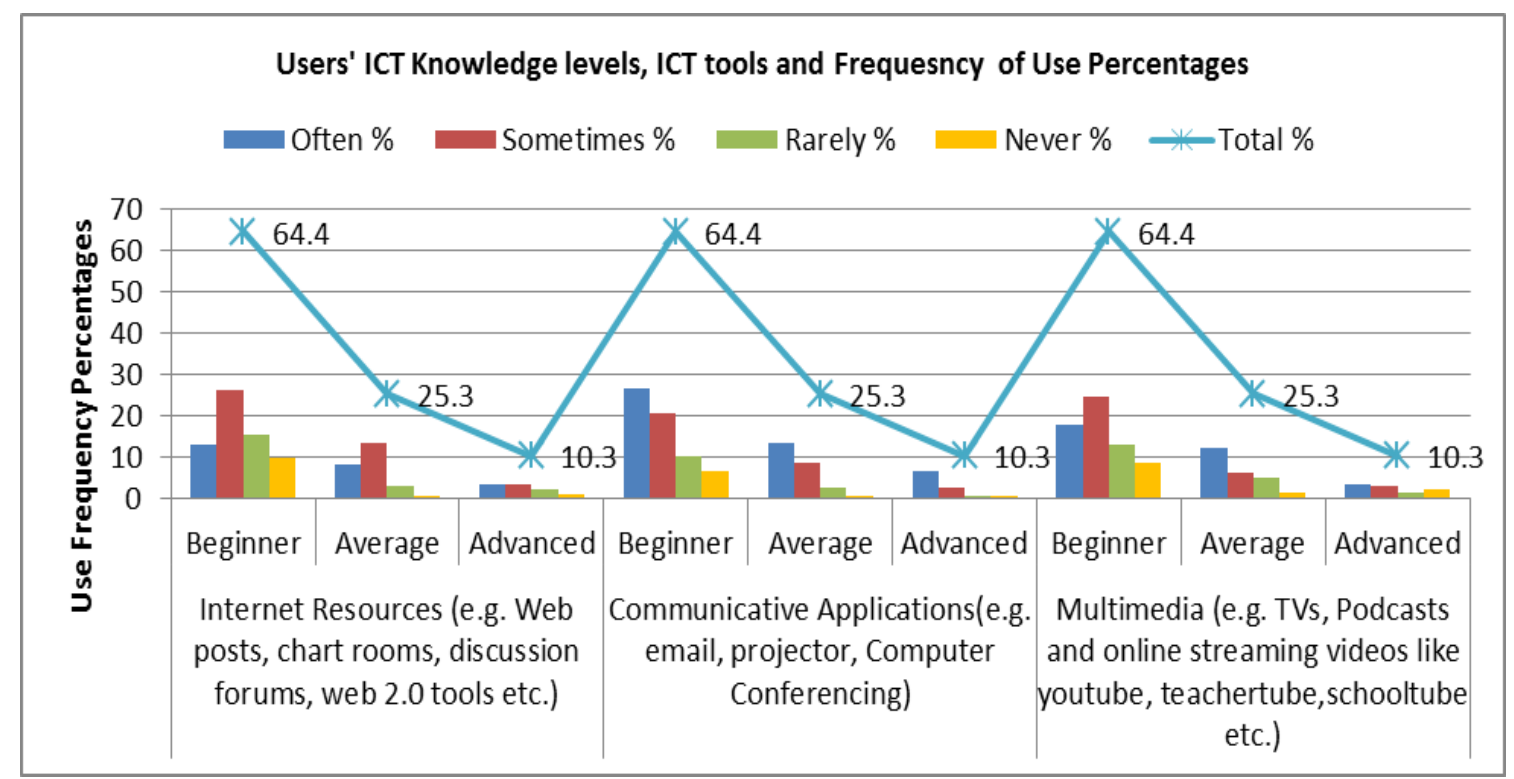

Figure 2: Teacher Trainees' ICT Knowledge Level and the Rate of Online Based ICT tools Practices $(\mathrm{N}=194)$ 
Results in Figure 2 revealed that majority of teacher trainees reported to have often or sometimes used the ICT tools assessed. A total of $25.3 \%$ beginner teacher trainees reported to have sometimes used internet resources, $25.3 \%$ beginner have often used communicative applications and $25.3 \%$ beginner have sometimes used multimedia tools. Both average users and advanced users who reported to have often/sometimes used internet resources, communicative applications and multimedia tools were very few.

\section{The Rate of Offline-based ICT tools Practices}

After teachers had completed rating their personal ICT knowledge level (competence) in which 1 represented beginner, 2 represented average and 3 represented advanced; then they were asked to rate their ICT use behavior (level of frequencies) with a range of ICT resources that do not necessarily depend on connectivity being provided. A rating of 1 represented never use, whereas the rating of 4 represented often use. Figure 3 provides summary of the teachers' ICT knowledge level against the ICT tools use frequency.

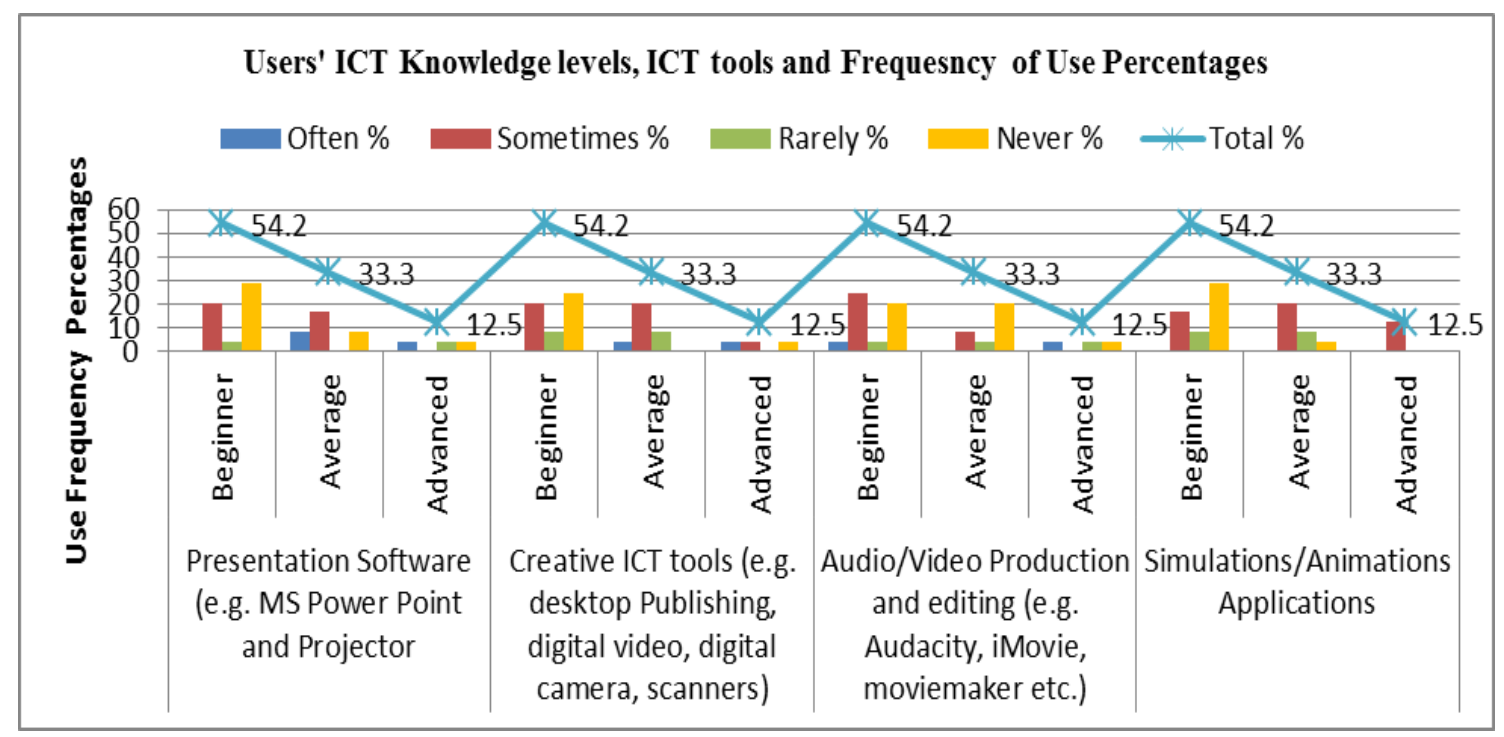

Figure 3. Teachers' ICT Knowledge Level and The Rate of Offline Based ICT tools Practices $(\mathrm{N}=24)$

Results in Figure 3 show that majority of teachers have reported often and sometimes used ICT tools, almost all of them were at either beginner or average level. However, the number of beginners who have never used presentation software (approximately 29\%), creative ICT tools (approx. 24\%), audio or video production (20\%) and simulation/animations applications (29\%) were reported above average and advanced users. Slight equal percentages of beginners and average users have sometimes used presentation software (20\% and $15 \%$ respectively) and creative tools (both 20\%). However, there were a slight big number of beginners and average users who have rarely or never used most of the ICT tools that were asked.

The study also assessed teacher trainees on the group of ICT tools that could be used offline (Users do not necessarily need internet access/connectivity).Users' ICT knowledge level was 
used as a key measure of how frequently beginner, average user and advanced user can be engaged with ICT tools in classroom. After teacher trainees had completed rating their personal ICT knowledge level (competence) in which 1 represented beginner, 2 represented average and 3 represented advanced; then they were asked to rate their ICT use behavior (level of frequencies) with a range of ICT resources that do not necessarily depend on connectivity being provided. A ranting of 1 represented never use, whereas the rating of 4 represented often use. Figure 4 provides summary of the teacher trainees' ICT knowledge level against the ICT tools use frequency.

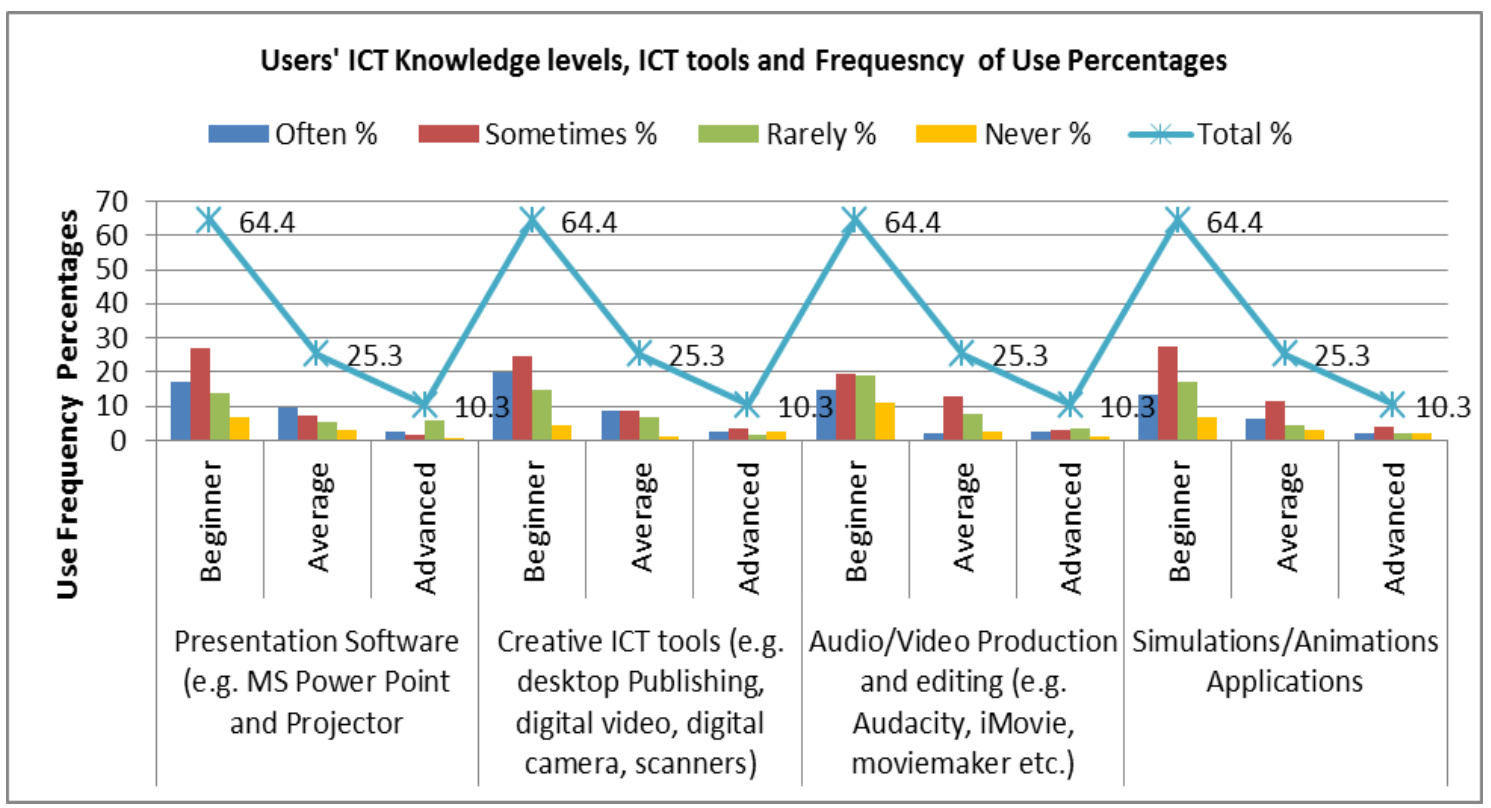

Figure 4. Teacher Trainees' ICT Knowledge Level and the Rate of Offline Based ICT tools Practices $(\mathrm{N}=194)$

Results in Figure 4 show that majority of teacher trainees who were beginners (64.4\%) have often or sometimes used all the four categories of ICTs. Majority of beginners (approximately 27\%) have sometimes used presentation software, $25.3 \%$ have sometimes used creative ICT tools, and approximately $19 \%$ have sometimes used audio/video production and editing tools while approximately $28 \%$ have sometimes used simulation/animation applications. The number of average users who reported often and sometimes was few.

\section{Teachers' Abilities to Use Digital Educational Resources as Pedagogical Tools}

The study asked teachers and teacher trainees to rate their level of preparedness in the use of ICT resources as a part of their teaching practices. A list of ICT tools covering numerous areas and practices were provided for them to write relevant choices. A rating of 1 represented prepared, 2 represented poorly prepared, and 3 represented not prepared. Table 6 provides a summary of the means and standard deviations on the level of ICT use preparedness. 
Table 6. Teachers' Preparedness on Application of Numerous ICT Tools and Classrooms Practices $(\mathrm{N}=218)$

\begin{tabular}{|c|c|c|c|c|}
\hline & \multicolumn{2}{|c|}{$\begin{array}{l}\text { Teachers } \\
\mathrm{N}=\mathbf{2 4}\end{array}$} & \multicolumn{2}{|c|}{$\begin{array}{l}\text { Teacher Trainees } \\
\quad \mathrm{N}=194\end{array}$} \\
\hline & Mean & STD & Mean & STD \\
\hline $\begin{array}{l}\text { Create multimedia presentations with scanners and digital } \\
\text { cameras }\end{array}$ & 2.04 & .908 & 2.84 & 1.111 \\
\hline $\begin{array}{l}\text { Use office applications (e.g. word processors, spreadsheets, } \\
\text { etc.) }\end{array}$ & 1.58 & .654 & 2.35 & 1.179 \\
\hline $\begin{array}{l}\text { Communicate and access online resources (e.g., e-mail, } \\
\text { Internet resources) }\end{array}$ & 1.54 & .721 & 2.39 & 1.187 \\
\hline Teach with presentations using computers and projectors & 1.71 & .955 & 2.55 & 1.147 \\
\hline Enhance professional productivity using interactive media & 2.17 & .702 & 2.86 & 1.071 \\
\hline $\begin{array}{l}\text { Use simulation/ animation/ applications that enhance content } \\
\text { for a lesson }\end{array}$ & 2.17 & .482 & 2.68 & 1.125 \\
\hline $\begin{array}{l}\text { Enhance research- based practices (project and problem- } \\
\text { based learning) }\end{array}$ & 2.13 & .741 & 2.86 & 1.033 \\
\hline $\begin{array}{l}\text { Support individuals and group learning activities using } \\
\text { technology }\end{array}$ & 1.83 & 637 & 2.42 & 1.075 \\
\hline Assess students' performance using technology & 1.96 & .859 & 2.46 & 1.097 \\
\hline $\begin{array}{l}\text { Use ICT resources for teaching and learning Basic Mathematics } \\
\text { and Science independently }\end{array}$ & 1.88 & .797 & 2.44 & 1.110 \\
\hline Use ICT that enhance the teaching approaches for a lesson & 2.25 & 1.032 & 2.51 & 1.044 \\
\hline Use ICT that enhance students learning for a lesson & 1.83 & .761 & 2.41 & 1.103 \\
\hline Teach using technology and non-technology resources & 2.04 & .624 & 2.21 & 1.096 \\
\hline
\end{tabular}

Preparedness mean level: 1= Prepared, 2= Poorly Prepared, 3= Not Prepared

Results in Table 6 show that the majority is prepared to use numerous digital educational resources that support blended learning implementation. Three mean levels of preparedness were established by the researcher for easy interpretation such as: prepared $(1<=$ Mean $>=$ $2.45)$, poorly prepared $(2.45<$ Mean $>=2.75)$ and Not prepared $(2.75<$ Mean $<=3.0)$. Teachers reported as prepared in all the ICT tools and classrooms practices that were asked at the means range $(1.54<=$ Mean $>=2.25)$. Majority of teacher trainees at a mean range $(2.21$ $<=$ Mean >=2.44) reported as prepared in basic office applications (e.g. word processors, spreadsheets etc.), communicate and access online resources (e.g. e-mail, Internet resources), support individuals and group learning activities using technology, use ICT resources for teaching and learning Basic Mathematics and Science independently, use ICTs that enhance students learning for a lesson and teach using technology and non-technology resources.

In addition, teacher trainees reported poorly prepared to teach with presentations using computers and projectors (Mean $=2.55, \mathrm{SD}=1.147$ ), use simulation/animation/applications that enhance content for a lesson $(M=2.68, S D=1.125)$, assess students' performance using technology (Mean $=2.46, \mathrm{SD}=1.097$ ) and use ICT that enhance the teaching approaches for a lesson (Mean $=2.51, \mathrm{SD}=1.044$ ). Majority of teacher trainees reported not prepared to create multimedia presentations with scanners and digital cameras $(M=2.84, S D=1.111)$, enhance 
professional productivity using interactive media $(M=2.86, S D=1.071)$ and enhance researchbased practices (project and problem-based learning) $(M=2.86, S D=1.033)$.

\section{Perceived Barriers on Teachers Digital Educational Recourses Practices}

As noted earlier, there exist internal and external limitations that hinder teachers from using educational ICT resources. Curriculum developers with influence on government's decision to integrate curriculum and ICT resources were assessed based on how they ranked various challenges that could limit the use of blended learning in schools. Ratings of 1 represented strongly disagree, 2 represented disagree, 3 represented uncertain, 4 represented agree and 5 represented strongly agree. Table 7 provides a summary of the means and standard deviations on the challenges as rated by curriculum deployment experts.

Table 7. Descriptive Statistics on the Perceptions of Curriculum Experts' on Challenges Facing Teachers when Implementing Blended Curriculum Contents ( $N=10)$

\begin{tabular}{lllll}
\hline Barriers to successful ICT use & Mean & Std. Dev. Minimum & Maximum \\
\hline Insufficient number of computers in schools & 4.70 & 0.483 & 4 & 5 \\
Lack of focus in the curriculum on the application of & 3.00 & 1.333 & 2 & 5 \\
ICTs & & & & \\
Teachers' lack of computer skills & 4.40 & 0.699 & 3 & 5 \\
Teachers' lack of interest in using ICTs for teaching & 2.60 & 0.843 & 1 & 4 \\
Teachers' lack of experience of using ICTs & 3.90 & 0.568 & 3 & 5 \\
Unreliable Internet connection & 4.20 & 0.632 & 3 & 5 \\
Lack of a framework that would address integration of & 3.70 & 1.252 & 2 & 5 \\
ICT in teaching and learning & & & \\
\hline
\end{tabular}

Mean: 1 = Strongly Disagree, 2=Disagree, 3=Uncertain, 4=Agree, 5=Strongly Agree

The results in Table 7 revealed that the most serious challenges respondents faced in ICT adoptions were the lack of computers in schools, lack of computer skills among teachers and unreliable Internet connection, with mean score range of 4.20 to 4.70 . The uncertain challenges were lack of curriculum and syllabi support on the use of blended curriculum contents, lack of ICT use framework, and teachers' lack of experience of working with ICT, both with mean range 3.00 to 3.90 .

\section{Interviews and Observation Results}

The Ministry of Education and Vocational Training (MoEVT) is the main body for initiating all the policies, future plans, and innovation strategies for the education system. The study interview session to the MoEVT officials was guided by two major questions: (1) What are the success and failure of the past ICT in education initiatives?; and (2) what are the future plans for facilitating sustainable ICT use in secondary education across the country? However, respondents presented different opinions; two statements were of value for this study. An interviewee from the secondary school department stated "videos on sciences practical have been developed and distributed to schools to be used as alternatives in areas where resources 
and teacher run short ". The study found that copies of DVDs collected from the department was valid to the syllabi but were not known to most of science teachers in schools. Another interviewee stated that "the increased number of students and shortage of teachers could be solved by using ICTS where schools with let say one teacher in mathematics, ICT can be used to supplement such deficits". However, the sustainability of future ICT implementation in education was thrown to the shortage of funding sources since most of the past initiatives depended heavily on donors.

The results on observations revealed that two schools (Kilakala and Lupanga) had received computers, LCD projectors, and multimedia systems and training to use them; however, only Kilakala secondary school had teachers and students actively using basic ICT resources in teaching and learning. Teachers at Lupanga were not actively using the ICT tools, they complained about lacking enough time for setting up the devices and making preparations.
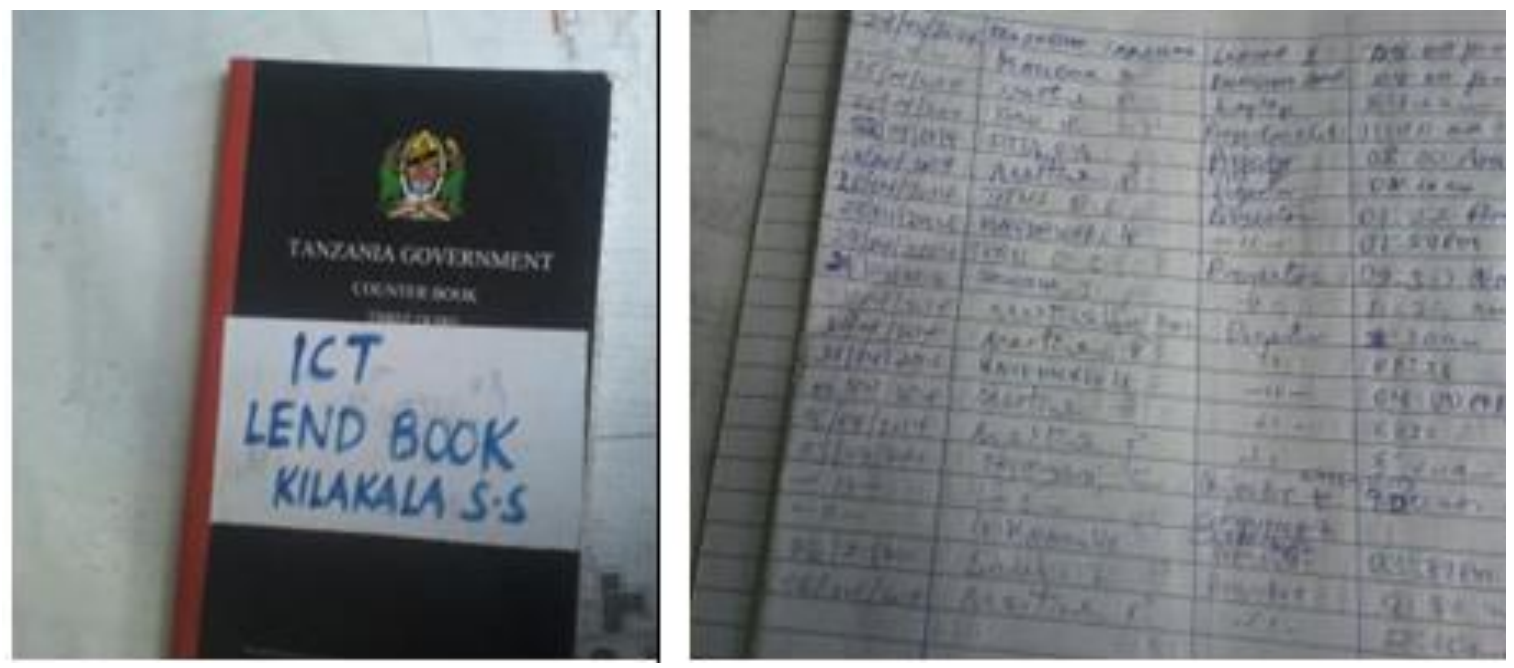

Figure 5 : Snapshot of ICT Tools Lending Records at Kilakala Secondary school

The other two schools (Kipera and Mongola) had no ICT infrastructures except for one laptop and one photocopy machine in the headmasters' offices used for managerial issues and examinations processing only.

\section{Discussions}

Teachers' ICT use knowledge, competencies and skills to use numerous digital educational resources for teaching are important aspects for the education system to meet the educational objectives that demand technology application. However, teachers' and teacher trainees' increased education level has not significantly contributed to their perceptions on an increased ICT use knowledge, competencies, and skills. Teachers with higher education could not perceive themselves as advanced users and the same applied to teacher trainees where year of study did not prove positively on the ICT knowledge level.

The results generally concur with Ndibalema (2014) which investigated teachers' attitudes towards the use of pedagogical ICT tools in Tanzanian Secondary Schools and found that low familiarity with ICT use as pedagogical tools among teachers was a serious problem. 
When teachers fail to acknowledge the pedagogical importance and applications of ICT tools, the teacher training institutions have failed to consider technology adoption opposed to Straub (2009) who considered technology use as a complex, developmental process that both the training institutions and teaching environment have to cultivate when addressing the cognitive, emotional, and contextual concerns.

The use of blended learning is usually attributed to the ability to support mixing traditional approaches and technology enhanced teaching and learning approaches that allow learners to learn at their own pace and time. The uses of digital educational resources as blended learning enabler are either offline accessed on the CD, DVD or online accessed over the internet. The lack of significant relationship between the education level and ICT knowledge level (competence) was associated with a large number of teachers and teacher trainees who reported themselves as beginner users regardless of their education level. However, the distribution of beginner users, average users, and advanced users was evenly distributed throughout numerous online and offline digital educational resources. Regardless of existing ICT knowledge level and the number of digital educational resources, teachers are able to use, given appropriate supports, they can gradually adjust their level of ICT use knowledge (Schibeci et al., 2008). Hence, teachers need to be assisted along the journey to ICT integration.

Teachers and teacher trainees' perceptions on the offline based ICT tools' practices were dissimilar in nature; high percentage of beginners' users who are teachers reported on often and sometimes while beginners who are teacher trainee at high percentages reported rarely and newer used. However, the amount and range of ICT resources available to the teachers have influence on the use made of ICT in subjects and classes; many teachers cannot use some forms of technology, progressively limiting the education system from harnessing the ICT benefits (Cox et al., 2003, p. 3). When the frequency of digital educational resources application among teachers and teacher trainees is high, this motivates students to learn using ICTs and also attracts the government to invest in the use of blended learning (an elearning model). Training that the teachers have obtained did not have clear impact on the level and diversity of technology use. Studies by Haydn and Barton(2007) who assessed how trainee teachers make progress in their ability to use ICT in subject teaching and Barton \& Haydn (2006) who assessed trainee teachers' on what helps them to use ICT effectively in their subject teaching both reported that trainees experiences and resources which they had encountered in the course of their training had not been helpful. In this study we find, no relationship between the ICT knowledge level perceived by most teachers and teacher trainees and the ability to use more ICT tools in classroom.

Respondents' perceptions on the preparedness in the adoption of digital educational resources and their abilities to efficiently carry out ICT pedagogical practices in classroom indicated a wide gap between teachers and teacher trainees. Majority of beginner users who were teachers believed they are prepared in an extensive range of ICT resources and practices compared to teacher trainees who reported as beginners and were only prepared in few ICT resources and also poorly prepared in others. In this study we assumed some of the perceptions as caused by lack of confidence. The study by Al-Senaidi, Lin, and Poirot (2009), which assessed the barriers to adopting technology for teaching and learning, reported a lack of confidence in ICT use among teachers can lead to lack of competence. The weakness revealed by teacher trainees on the application of technology in teaching is an indication of the weakness in their trainers in technology use competences and inability to 
transfer such practices to their peers. A study by Tamim et al. (2011) argued that that one of technology's main strengths lie in supporting students' efforts to achieve rather than acting as a tool for delivering content. However teachers' preparedness could be contributed to availing negative factors that are related to ICT resources availability, lack of competence, and pedagogical models or unclear goals for using ICTs. The teachers' attitude levels towards the use of ICT need to have direct relationships with the use of ICT for educational purposes (European Union, 2013, p. 16). This means that teacher trainees need to be trained in the ICT practices environment to be able to use ICT; as reported by Kalogiannakis (2008) on training with ICT for ICT from the trainee's perspective that there was positive preparedness when teachers were trained to involve ICT practices. It is more likely that teacher trainees may enter job market with incompetence in pedagogical ICT skills which may arise more training needs and expenses in later days. This means personal characteristics (computer training background) have impact in the future of ICT use (Albirini, 2006).

This study identified both internal and external critical barriers which were evident. Internal barriers were teachers' lack of basic computer skills, teachers' lack of experience to use ICTs and teachers' fear of technology. External challenges were, Tanzania as nation face unsustainable financial constraints for funding ICT in education initiatives, lack of curriculum and syllabi contextual support to the use of blended learning contents, unreliable Internet connection, teachers' lack of motivation to use technology, and insufficient number of computers in schools, also reported by (Buabeng-Andoh, 2012) as among critical challenges in a developing nation of Ghana. However, resistance to change was also revealed by a number of teachers turn up for using ICT resources in schools where training and basic ICT resources had been provided by the government. Most of the available ICT tools in schools were offered through donor-funded ICT projects, which means that government support is more political than reality.

\section{Conclusions and Recommendations}

This study has demonstrated that teachers were passionate to know and use the blended curriculum contents in classrooms but few of them have failed to use ICT tools due to the prevailing avoidable and unavoidable limitations. Teachers' education level cannot be used as the measure to determine how ICT resources can be used to teach students in secondary schools. ICT resources investment, availability, and accessibility in some schools can become a burden if other factors are not well-managed. The level of ICT knowledge among teachers and teacher trainees and its linkage with the efficiency to use blended learning contents determines how users were trained and prepared to use ICT resources pedagogically. The challenges secondary schools face in relation to ICT use are complex and they should not be faced from single direction.

This study visualizes a domain of technology integration in secondary education, points to teachers, teacher trainees, technology use, teacher training institutions and the teaching and learning environment as complex as planning for harmonization of them. The ability for teachers to use technology as pedagogical tools is influenced by many factors, that if one has not well-planned then the others could lead to wastage of resources and failure in the educational objectives. 
Major limitation to this study could be that the study conclusion is based on the perception so that, if experimental research design is carried out, this may add more strength to these results. A combined review of literature and empirical data analyzed here identified a range of practices which may enhance teachers' pedagogical practices that integrate ICT effectively into teaching and learning. These included teachers' characteristics such as:

- Subject matter knowledge and the relationship between a choice of ICT resources and the concepts, processes, and skills to use them as pedagogical tools

- Ability to select appropriate ICT resources, which will help them, meet the specific teaching and learning objectives for the particular level of learners

- Confidence to walk in a class and decide using a range of ICT resources via frequent practice and use beyond one or two familiar applications.

- Ability to prepare lesson plans that involves tasks where ICT is used in ways which will motivate learners and challenge them to understand and promote greater thinking and creativity.

Based on the findings of this study, it is recommended that a goal-oriented teacher training technology model be developed. Teacher training should focus on realizing the competences in the technological, pedagogical, and content knowledge (TPACK) as inseparable factors. The use of ICT in teacher training institutions and secondary schools should seek to solve problems that are aligned to the objectives of the education system rather than deploying ICT for the sake of general perception. While ICTs continue to emerge, the significant impact on teaching and learning should be harnessed within the teacher training programs as a subject, practical pedagogical tool, and resources for knowledge growth. In addition, we recommend further studies for testing teachers and tutors in the field for determining training needs and the existing gap. The use of mobile devices and curriculum based mobile apps, which are not emphasized in this study, should also be considered as most relevant for the current digital generation of learners and teachers.

\section{References}

Aduwa-Ogiegbaen, S. E. O. (2009). Nigerian inservice teachers' self-assessment in core technology competences and their professional development needs in ICT. Journal of Computing in Teacher Education, 26(1), 17-28. http://doi.org/10.1080/10402454.2009. 10784627

Albirini, A. (2006). Teachers' attitudes toward information and communication technologies: The case of Syrian EFL teachers. Computers \& Education, 47(4), 373-398.

Albugami, S. \& Ahmed, V. (2015). Success factors for ICT implementation in Saudi secondary schools: From the perspective of ICT directors, head teachers, teachers and students. International Journal of Education and Development Using Information and Communication Technology, 11(1), 36-54.

Alonso, F., López, G., Manrique, D., \& Viñes, J. M. (2005). An instructional model for web-based e-learning education with a blended learning process approach. British Journal of Educational Technology, 36(2), 217-235. http://doi.org/10.1111/j.1467-8535.2005. 00454.x 
Al-Senaidi, S., Lin, L., \& Poirot, J. (2009). Barriers to adopting technology for teaching and learning in Oman. Computers \& Education, 53(3), 575-590.

Al-Zaidiyeen, N. J., Mei, L. L., \& Fook, F. S. (2010). Teachers' Attitudes and Levels of Technology Use in Classrooms: The Case of Jordan Schools. International Education Studies, 3(2), 211.

Andersson, A. \& Grönlund, Å. (2009). A conceptual framework for E-learning in developing countries: A critical review of research challenges. EJISDC, 38(8), 1-16.

Andersson, B., Nfuka, E. N., Sumra, S., Uimonen, P., \& Pain, A. (2014). Evaluation of Implementation of ICT in teachers' colleges project in Tanzania (Final Evaluation Report No. Sida61745en urn: nbn:se:sida-61745en). Stockholm, Sweden: Swedish International Development Cooperation Agency (Sida). Retrieved on 12 December 2015 from http:// sidapublications.citat.se/interface/stream/stream.asp

Avidov-Ungar, O., \& lluz, I. E. (2014). Levels of ICT integration among teacher educators in a teacher education academic college. Interdisciplinary Journal of E-Learning and Learning Objects, 10, 195-216.

Badia, A., Meneses, J., Sigalés, C., \& Fàbregues, S. (2014). Factors affecting school teachers' perceptions of the instructional benefits of digital technology. Procedia-Social and Behavioral Sciences, 141, 357-362. http://doi.org/10.1016/j.sbspro.2014.05.063

Baker, D., Bliss, A., Chung, R., \& Reynolds, C. (2013). E-learning for teacher training in Tanzania : Policy, players, models, and recommendations for the Asante Africa Foundation (Introduction to Policy Analysis No. PP200). Berkeley, California: University of California. Retrieved on 12 December 2015 from http://www.asanteafrica.org/wpcontent/uploads/2015/06/E-Learning.-TZ-Teachers.2013.pdf

Barton, R. \& Haydn, T. (2006). Trainee teachers' views on what helps them to use information and communication technology effectively in their subject teaching. Journal of Computer Assisted Learning, 22(4), 257-272. http://doi.org/10.1111/j.1365-2729.2006.00175.x

Berk, R. A. (2009). Multimedia teaching with video clips: TV, movies, YouTube, and mtvU in the college classroom. International Journal of Technology in Teaching and Learning, 5(1), 121.

Bland, J. M. \& Altman, D. G. (1997). Cronbach's alpha. BMJ : British Medical Journal, 314(7080), 572.

Brown, S. (2010). From VLEs to learning webs: the implications of Web 2.0 for learning and teaching. Interactive Learning Environments, 18(1), 1-10. http://doi.org/10.1080/ 10494820802158983

Buabeng-Andoh, C. (2012). Factors influencing teachers' adoption and integration of information and communication technology into teaching: A review of the literature. International Journal of Education and Development Using ICT, 8(1). Retrieved on 12 December 2015 from http://ijedict.dec.uwi.edu/viewarticle. php?id=1361

Cox, M., Webb, M., Abbott, C., Blakeley, B., Beauchamp, T., \& Rhodes, V. (2003). ICT and pedagogy: A review of the research literature (No. DfES/0793/2003). British Educational Communications and Technology Agency (Becta). Retrieved on 12 December 2015 from https://wiki.inf.ed.ac.uk/twiki/pub/ECHOES/ICT/ict_pedagogy_summary.pdf 
Daniel, S. J. (2009). Is e-learning true to the principles of technology? (Vol. 2009). Presented at the E-Learn: World Conference on E-Learning. Retrieved on 12 December 2015 from /p/33043/

Dumont, H. \& Istance, D. (2010). Analysing and designing learning environments for the 21st century (The nature of learning: Using research to inspire practice). OECD.

European Union. (2013). Survey of schools: ICT in education (Final Study Report No. SMART-Nr 2010/0039). Luxembourg, Belgium: European Commission. Retrieved on 12 December 2015 from https://ec.europa.eu/digital-agenda/sites/digital-agenda/files/KK-31-13-401EN-N.pdf

Farrell, G., Isaacs, S., \& Trucano, M. (2007). Survey of ICT and education in Africa (Country Reports No. Volume 2 : 53) (p. 587). Washington, DC: infoDev/World Bank. Retrieved on 12 December 2015 from http://www.infodev.org/en/Publication.354.html.

Felvégi, E. \& Matthew, K. I. (2012). eBooks and Literacy in K-12 Schools. Computers in the Schools, 29(1-2), 40-52. http://doi.org/10.1080/07380569.2012.651421

GESCI. (2011a). Report on the review of modules, monitoring and evaluation tools and training of trainers project: Teaching and learning science, mathematics and English in secondary schools using ICT (Project Evaluation Report). Mpwapwa Teachers College - Tanzania: Ministry of Education and Vocational Training (MoEVT)/GESCI.

GESCI. (2011b, July). Teaching and learning science, mathematics and English in secondary schools using ICT in Tanzania [Technology, Innovation and Education news and Resources]. Retrieved on 12 December 2015 from July 24, 2014, from http://www. gesci.org/tanzania-sme.html

Ham, V., Gilmore, A., Kachelhoffer, A., Morrow, D., Moeau, P., \& Wenmoth, D. (2002). Evaluation of the "New Initiatives" in "Interactive Education: An information and communication technology (ICT) Strategy for Schools." New Zealand: Ministry of Education. Retrieved on 12 December 2015 from http://www.educationcounts.govt.nz/ __data/assets/pdf_file/0010/7489/ict-pd-final-web.pdf

Haydn, T. \& Barton, R. (2007). Common needs and different agendas: How trainee teachers make progress in their ability to use ICT in subject teaching. Some lessons from the UK. Computers \& Education, 49(4), 1018-1036. http://doi.org/10.1016/j.compedu.2005.12. 006

Henry, P. (2001). E-learning technology, content and services. Education + Training, 43(4/5), 249-255. http://doi.org/10.1108/EUM0000000005485

Holt, D., Segrave, S., \& Cybulski, J. L. (2012). Professional education using e-simulations: benefits of blended learning design (I). Hershey PA: IGI Global.

Hooker, M., Mwiyeria, E., \& Verma, A. (2011). ICT competency framework for teachers (ICTCFT): Contextualization and piloting in Nigeria and Tanzania (World Bank and GESCI initiative synthesis report No. Draft). Dar-es-Salaam, Tanzania: Ministry of Education and Vocational Training (MoEVT),Tanzania. Retrieved on 12 December 2015 from http://www.gesci.org/assets/files/Tanzania_Needs_Assessment_Report_Draft_Final_23 0911\%20_3_.pdf

IICD. (2014). ICT in the classroom for quality education. International Institute for Communication and Development (IICD). 
Intel Corporation. (2012). Designing blended learning. Intel Corporation. Retrieved on 12 December 2015 from http://engage.intel.com/

Jia, J., Xiang, D., Ding, Z., Chen, Y., Wang, Y., Bai, Y., \& Yang, B. (2013). An effective approach using blended learning to assist the average students to catch up with the talented ones. Knowledge Management \& E-Learning, 5(1), 25-41.

Jones, A. (2004). A review of the research literature on barriers to the uptake of ICT by teachers. (No. Version 1). British Educational Communications and Technology Agency (Becta). Retrieved on 12 December 2015 from http://dera.ioe.ac.uk/1603/1/becta_ 2004_barrierstouptake_litrev.pdf

Kalogiannakis, M. (2008). Training with ICT for ICT from the trainee's perspective. A local ICT teacher training experience. Education and Information Technologies, 15(1), 3-17. http://doi.org/10.1007/s10639-008-9079-3

Keane, T., Keane, W. F., \& Blicblau, A. S. (2014). Beyond traditional literacy: Learning and transformative practices using ICT. Education and Information Technologies, 1-13. http://doi.org/10.1007/s10639-014-9353-5

Knox, J. (2014). Digital culture clash: "massive" education in the e-learning and digital cultures MOOC. Distance Education, 35(2), 164-177. http://doi.org/10.1080/01587919.2014. 917704

Kothari, C. R. (2004). Research methodology: Methods and techniques $\left(2^{\text {nd }}\right.$ ed.). New Delhi, India: New Age International.

Lim, C. P. (2006). Effective integration of ICT in Singapore schools: pedagogical and policy implications. Educational Technology Research and Development, 55(1), 83-116. http://doi.org/10.1007/s11423-006-9025-2

Markauskaite, L. (2007). Exploring the structure of trainee teachers' ICT literacy: The main components of, and relationships between, general cognitive and technical capabilities. Educational Technology Research and Development, 55(6), 547-572. http://doi.org/10.1007/s11423-007-9043-8

Mckensey \&Company. (2011). Internet matters: Sizing the Internet economy (McKensey Global Institute Research Report) (p. 70). Mckensey \&Company. Retrieved on 12 December 2015 from http://www.mckinsey.com/features/sizing_the_internet_economy

Mumtaz, S. (2000). Factors affecting teachers; use of information and communications technology: a review of the literature. Journal of Information Technology for Teacher Education, 9(3), 319-342. http://doi.org/10.1080/14759390000200096

Ndibalema, P. (2014). Teachers' attitudes towards the use of information communication technology (ICT) as a pedagogical tool in secondary schools in Tanzania: The Case of Kondoa District. International Journal of Education and Research , 2(2), 1-16.

Nyirenda, M. (2013, December 2). Planning for ICT literacy in public schools in Tanzania. The Guardian. Dar-es-Salaam, Tanzania. Retrieved on 12 December 2015 from http://www. ippmedia.com/frontend/?l=62206

OECD. (2015). Students, computers and learning. Paris.: OECD Publishing. Retrieved on 12 December 2015 from http://www.oecd-ilibrary.org/education/students-computers-andlearning_9789264239555-en 
Olson, J., Codde, J., deMaagd, K., Tarkelson, E., Sinclair, J., Yook, S., \& Egidio, R. (2011). An Analysis of e-Learning impacts \& best practices in developing countries: With reference to secondary school education in Tanzania (Information \& Communication Technology for Development). Michigan, USA: Michigan State University. Retrieved on 12 December 2015 from http://cas.msu.edu/wp-content/uploads/2013/09/E-Learning-WhitePaper_oct-2011.pdf

Pankin, J., Roberts, J., \& Savio, M. (2012, July). Blended learning at MIT. Massachusetts Institute of Technology Repository. Retrieved on 12 December 2015 from http://web.mit.edu/training/trainers/resources/blended_learning_at_mit.pdf

Patnoudes, E. (2014, June 30). How tomorrow's tech helps teachers today. Retrieved on 4 July 2014 from http://www.edtechmagazine.com/k12/article/2014/06/how-tomorrowstech-helps-teachers-today

Queirós, R., \& Leal, J. P. (2010). ELearning frameworks: A survey. In INTED2010 Proceedings (Vol. 8-10 March, 2010., pp. 1345-1354). Valencia, Spain.: International Academy of Technology, Education and Development (IATED). Retrieved on 12 December 2015 from http://library.iated.org/view/QUEIROS2010ELE

Saliba, G., Rankine, L., \& Cortez, H. (2013). Fundamentals of blended learning. University of Western Sydney. Retrieved on 12 December 2015 from http://www.uws.edu.au/ data/assets/pdf_file/0004/467095/Fundamentals_of_Blended_Learning.pdf

Santos, J. R. A. (1999). Cronbach's alpha: A tool for assessing the reliability of scales. Journal of Extension, 37(2), 1-5.

Schibeci, R., MacCallum, J., Cumming-Potvin, W., Durrant, C., Kissane, B., \& Miller, E. (2008). Teachers' journeys towards critical use of ICT. Learning, Media and Technology, 33(4), 313-327. http://doi.org/10.1080/17439880802497065

Spaulding, M. W. (2007). Comparison of preservice and in-service teachers' attitudes and perceived abilities toward integrating technology into the classroom (Unpublished doctoral thesis). The University of Memphis, United States. Retrieved on 12 December 2015 from http://www.editlib.org/p/127253/

Straub, E. T. (2009). Understanding technology adoption: Theory and future directions for informal learning. Review of Educational Research, 79(2), 625-649. http://doi.org/10.3102/0034654308325896

Swarts, P. \& Wachira, E. M. (2010). Tanzania: ICT in education situational analysis (Survey Results Report) (p. 67). Global e-Schools and Communities Initiative(GESCI). Retrieved on 12 December 2015 from http://www.gesci.org/assets/files/Knowledge\%20Centre/ Situational\%20Analysis_Tanzania.pdf

Tamim, R. M., Bernard, R. M., Borokhovski, E., Abrami, P. C., \& Schmid, R. F. (2011). What forty years of research says about the impact of technology on learning: A second-order meta-analysis and validation study. Review of Educational Research, 81(1), 4-28. http://doi.org/10.3102/0034654310393361

The World Bank Group. (2003). ICT and millennium development goals (MDGs) (ICT and MDGs No. 27877). Washington D.C.USA: World Bank Group's Global ICT Department. Retrieved on 12 December 2015 from http://documents.worldbank.org/curated/en/2003/12/ 5129003/ict-mdgs-world-bank-group-perspective 
Thorne, K. (2003). Blended learning: How to integrate online and traditional learning. London, UK: Kogan Page.

UNESCO. (2011). UNESCO ICT competency framework for teachers (Framework Document) (p. 95). de Fontenoy, Paris: UNESCO. Retrieved on 12 December 2015 from http://unesdoc. unesco.org/images/0015/001562/156209E.pdf

United Republic of Tanzania. (2007). Information \& communication technology (ICT) policy for basic education (Policy Document) (pp. 1-30). Dar es Salaam, Tanzania: Ministry of Education and Vocational Training(MoEVT). Retrieved on 12 December 2015 from http://www.moe.go.tz/index.php?option=com_docman\&task=doc_download\&gid=226 \&ltemid=619

Voogt, J., Knezek, G., \& Roblin, N. P. (2015). Research-informed strategies to address educational challenges in a digitally networked world. Education and Information Technologies, 20(4), 619-623. http://doi.org/10.1007/s10639-015-9430-4

Welsh, E. T., Wanberg, C. R., Brown, K. G., \& Simmering, M. J. (2003). E-learning: emerging uses, empirical results and future directions. International Journal of Training and Development, 7(4), 245-258. http://doi.org/10.1046/j.1360-3736.2003.00184.x

Zhang, D. \& Nunamaker, J. F. (2003). Powering e-learning in the new millennium: an overview of e-learning and enabling technology. Information Systems Frontiers, 5(2), 207-218.

Correspondence: Patrick D. Kihoza, Assistant Professor, Nelson Mandela African Institution of Science and Technology, Arusha, Tanzania 